\title{
The importance of mesophyll conductance in regulating forest ecosystem productivity during drought periods
}

\author{
TREVOR KEENAN*, SANTI SABATE*† and CARLOS GRACIA*† \\ ${ }^{*}$ CREAF, Autonomous University of Barcelona (UAB), 08193, Barcelona, Spain, $\dagger$ Department of Ecology, University of Barcelona \\ (UB), 08007, Barcelona, Spain
}

\begin{abstract}
Water availability is the most limiting factor to global plant productivity, yet photosynthetic responses to seasonal drought cycles are poorly understood, with conflicting reports on which limiting process is the most important during drought. We address the problem using a model-data synthesis approach to look at canopy level fluxes, integrating twenty years of half hour data gathered by the FLUXNET network across six Mediterranean sites. The measured canopy level, water and carbon fluxes were used, together with an inverse canopy ecophysiological model, to estimate the bulk canopy conductance, bulk mesophyll conductance, and the canopy scale carbon pools in both the intercellular spaces and at the site of carboxylation in the chloroplasts. Thus the roles of stomatal and mesophyll conductance in the regulation of internal carbon pools and photosynthesis could be separated. A quantitative limitation analysis allowed for the relative seasonal responses of stomatal, mesophyll, and biochemical limitations to be gauged. The concentration of carbon in the chloroplast was shown to be a potentially more reliable estimator of assimilation rates than the intercellular carbon concentration. Both stomatal conductance limitations and mesophyll conductance limitations were observed to regulate the response of photosynthesis to water stress in each of the six species studied. The results suggest that mesophyll conductance could bridge the gap between conflicting reports on plant responses to soil water stress, and that the inclusion of mesophyll conductance in biosphere-atmosphere transfer models may improve their performance, in particular their ability to accurately capture the response of terrestrial vegetation productivity to drought.
\end{abstract}

Keywords: conductance limitations, drought, FLUXNET, Mediterranean climate, mesophyll conductance, photosynthesis, water stress

Received 12 March 2009; revised version received 2 June 2009 and accepted 16 June 2009

\section{Introduction}

Our understanding of the potential of terrestrial net primary productivity is not complete without a clear understanding of the main limitations on leaf photosynthesis (Loreto \& Centritto, 2008). Water availability is known to be the main limiting factor to global plant photosynthesis (Boyer, 1982), in particular in arid or semi-arid ecosystems within Mediterranean climate regions (Nemani et al., 2003). Projections of climate change suggest that higher temperatures, and increased potential evapotranspiration, as well as changes in seasonal precipitation patterns (IPCC WGI, 2007), will

Correspondence: T. Keenan, tel. + 003493581 2915, fax + 003493 581 4151, e-mail: t.keenan@creaf.uab.es aggravate the seasonal drought stress characteristic to Mediterranean ecosystems (Giorgi et al., 2004; Wang, 2005; Giorgi, 2006; Beniston et al., 2007). Our understanding of the impacts of changing climate on these ecosystems is poor due to a lack of understanding concerning ecophysiological responses to soil moisture stress and consequent effects on the cycling of carbon and water (Loreto \& Centritto, 2008).

The effect of water stress on plant photosynthesis and stomatal conductance has been widely studied (Chaves, 1991; Wilson et al., 2000; Chaves et al., 2002). It has long been accepted that stomatal control is the main driver behind photosynthetic response to water stress (e.g., Cornic, 2000), limiting available leaf intercellular carbon, thus slowing down photosynthesis and conserving water ('classical stomatal control'). Yet, the involvement 
of nonstomatal limitations has also been suggested which takes the form of an additional metabolic or biochemical constraint (e.g., Smirnoff \& Stewart, 1985; Vassey \& Sharkey, 1989; Maroco et al., 2002; Reichstein et al., 2002). Model-data studies have shown that these biochemical limitations are necessary for explaining drought responses of carbon and water fluxes from forest canopies (Rambal et al., 2003; Reichstein et al., 2003; Keenan et al., 2009b), and are backed up by measurements of water stress-related changes in photosynthetic capacity in the field (e.g., Xu \& Baldocchi, 2003). Most studies, however, do not take into account mesophyll conductance. Changes in mesophyll conductance have been suggested to be one of the possible nonstomatal physiological reactions to stress which can play a part in the limitation of photosynthesis (e.g., Grassi \& Magnani, 2005; Niinemets et al., 2005; Warren, 2008b). Much debate still remains as to the dynamic between stomatal and nonstomatal limitations at different levels of water stress (Flexas et al., 2002, 2004; Lawlor \& Cornic, 2002; Loreto \& Centritto, 2008) and there is large uncertainty as to the role played by stress-related changes in mesophyll conductance.

Mesophyll conductance has historically been assumed to be infinite, with stomatal control given the sole role in the control of photosynthesis in waterstressed conditions through the control of the leaf intercellular $\mathrm{CO}_{2}$. However, there is increasing evidence that mesophyll conductance is indeed finite (Ethier \& Livingston, 2004; Flexas et al., 2004, 2008; Niinemets et al., 2009a), and it has been demonstrated to change during leaf development (Miyazawa \& Terashima, 2001), with nutrient availability (Warren, 2004), with available radiation (Niinemets et al., 2006), leaf temperature (Bernacchi et al., 2002), salinity (Loreto et al., 2003), ambient $\mathrm{CO}_{2}$ concentrations (Flexas et al., 2007), and to be related to soil water availability (Flexas et al., 2002, 2004; Warren et al., 2004; Grassi \& Magnani, 2005; Warren, 2008a). Finite $G_{m}$ would lead to a lower concentration of $\mathrm{CO}_{2}$ reaching the chloroplast and any changes in $G_{\mathrm{m}}$ during periods of low soil water availability could potentially play an important role in controlling photosynthetic responses to water stress (Jones, 1973; Flexas et al., 2008; Niinemets et al., 2009a). This could also account for the differences observed in WUE estimated from FLUXNET data in a conventional way (i.e. not accounting for mesophyll conductance) and WUE estimated by sap flow measurements (Rambal et al., 2003).

The logistic complications of making canopy measurements of water stress effects on leaf photosynthesis and $G_{\mathrm{m}}$ over long periods makes it difficult to scale up results to trees in woodland conditions over entire seasons and years. On top of this, only a few studies have used quantitative analysis techniques to separate the different limitations to photosynthesis (Ellsworth, 2000; Wilson et al., 2000). These two problems are being approached by recent advances in inverse modelling techniques which allow for the estimation of leaf ecophysiological parameters from eddy-covariance flux data (e.g., Rambal et al., 2003; Reichstein et al., 2003; Wang et al., 2007; Carvalhais et al., 2008; Lasslop et al., 2008 ) and recently the consideration of possible limitations of photosynthesis due to a variable mesophyll conductance (Grassi \& Magnani, 2005).

In this paper, we use data from multiple FLUXNET (http://daac.ornl.gov/FLUXNET/) sites to quantify the role of both stomatal conductance and mesophyll conductance in regulating forest ecosystem productivity during drought periods. Both bulk canopy stomatal and mesophyll conductance were calculated from the FLUXNET data, using an inversion of the McNaughton and Black equation (McNaughton \& Black, 1973), the Harley variable $J$ method (Harley et al., 1992), and an ecophysiological process-based photosynthesis-conductance model coupling (Farquhar et al., 1980; Leuning et al., 1995) together with a canopy distribution model (Campbell, 1986; Dai et al., 2004; Keenan et al., 2009b), thus describing foliar photosynthesis and conductances as distributed through the canopy. The resulting responses of the bulk canopy leaf intercellular and chloroplast carbon pool concentrations to changes in soil water availability were thus assessed. A quantitative analysis (Grassi \& Magnani, 2005) allowed for the separation and quantification of the different limitations to forest productivity during drought.

\section{Materials and methods}

\section{FLUXNET site data and data manipulation}

The sites chosen cover six dominant species, over a wide range of Mediterranean environmental conditions, and include Quercus ilex, Quercus cerris, Fagus sylvatica, Pinus halepensis, Pinus ponderosa, and Quercus douglasii, respectively. Three of the studied sites are situated in Europe (Puéchabon, France; Roccarespampani, Italy; Collelongo, Italy), under the CarboEurope-IP project, one site in Israel (Yatir) and two sites in the United States (Blodgett and Tonzi, CA), under the AMERIFLUX project (Table 1). The most common Mediterranean environments are covered, from a savannah-type ecosystem (Tonzi, CA) to semi-arid (Yatir, Israel), to mountainous (e.g., Collelongo, Italy; Blodgett, CA), across the three continents. FLUXNET provides continuous measurement of carbon dioxide (broken down into net assimilation and ecosystem respiration) and water fluxes on a seasonal basis with half-hourly discrimination (Friend et al., 2007). 
Table 1 Details of the FLUXNET sites used in this study

\begin{tabular}{|c|c|c|c|c|c|c|c|c|}
\hline Species & Site location & Period & Longitude & Latitude & Altitude & $\begin{array}{l}\text { Annual } \\
\text { precipitation } \\
(\mathrm{mm})\end{array}$ & $\begin{array}{l}\text { Soil water } \\
\text { maximum } \\
\left(\mathrm{kg} \mathrm{m}^{-2}\right)\end{array}$ & $\begin{array}{l}\text { Mean } \\
\text { temperature } \\
\left({ }^{\circ} \mathrm{C}\right)\end{array}$ \\
\hline Quercus ilex & Puéchabon, France* & 2001-2004 & $3^{\circ} 35^{\prime}$ & $43^{\circ} 44^{\prime}$ & 270 & 1028 & 210 & 13.7 \\
\hline Quercus cerris & Rocarespampani, Italy $^{\dagger}$ & 2002-2004 & $11^{\circ} 55^{\prime}$ & $42^{\circ} 23^{\prime}$ & 223 & 862 & 480 & 14.9 \\
\hline Fagus sylvatica & Collelongo, Italy ${ }^{\ddagger}$ & 1998-1999 & $13^{\circ} 35^{\prime}$ & $41^{\circ} 50^{\prime}$ & 1560 & 1181 & 287 & 7.6 \\
\hline Pinus ponderosa & Blodgett Forest, $\mathrm{CA}^{\S}$ & 2001-2004 & $-120^{\circ} 37^{\prime}$ & $38^{\circ} 53^{\prime}$ & 1315 & 1402 & 582 & 11.9 \\
\hline Quercus douslasii & Tonzi, CA & 2002-2006 & $-120^{\circ} 58^{\prime}$ & $38^{\circ} 26^{\prime}$ & 177 & 601 & 270 & 16.3 \\
\hline Pinus halepensis & Yatir Forest, Israel ${ }^{\|}$ & 2001-2003 & $35^{\circ} 30^{\prime}$ & $31^{\circ} 20^{\prime}$ & 650 & 279 & 215 & 18.7 \\
\hline
\end{tabular}

*Allard et al. (2008).

${ }^{\dagger}$ Kowalski et al. (2004).

"Valentini et al. (1996).

${ }^{\S}$ Goldstein et al. (2000).

"Baldocchi et al. (2004).

"Grunzweig et al. (2003).

New flux separation techniques now give the improved level 4 data set (Reichstein et al., 2005), used in this study.

\section{Fractional soil water storage}

Understanding the response of observed carbon and water fluxes to changes in soil moisture requires the seasonal evolution of soil water content to be known. In the absence of such measurements over the entire rooting profile at each site, daily relative soil water content [RSWC - the total soil water in the soil column relative to maximum soil moisture content (Table 1)] at each site was reconstructed using a simple water balance model. This approach inverts the evapotranspiration rate inferred from the measured latent heat flux, and determines the soil water balance with inputs from precipitation and outputs to run-off and belowground drainage (as in Keenan et al., 2009b). Run-off is calculated as a percentage of precipitation, and depends on the soil hydraulic gradient and porosity of the soil upper layer. Drainage is calculated to be inversely proportional to fractional soil water content (calculated as in Honeysett \& Ratkowsky, 1989; Gracia et al., 1999; see Keenan et al., 2009b for more details).

Both intersite and interannual soil water variability is large, giving a broad range of water stress responses in each of the six species with a particularly strong drought experienced in 2003 at the European sites. The Blodgett site soil water content shows little interannual variability due to the lack of interannual variability in its climate during the studied period, and small levels of water stress were experienced. In comparison, at Puéchabon, soil water varies over a large range, with levels reaching a prolonged low during 2003. This drought period is also reflected at the Roccarespampani site, with soil water levels in 2003 reaching half those of 2004. Yatir is a 'man-made' forest in a very arid region of Israel and suffers annual periods of strong drought stress. Each site experiences different degrees of water stress-related decreases in assimilation rates and observed evapotranspiration. Reconstructed seasonal soil water cycle details are presented in Keenan et al. (2009b).

\section{Calculation of bulk canopy conductance and bulk leaf intercellular carbon dioxide concentrations}

Bulk canopy conductance $\left(G_{\mathrm{c}}\right)$ is the leaf-surface conductance to water vapour $\left(g_{\mathrm{s}}\right)$ scaled to the canopy level, expressed on a ground-area basis. It can be estimated from the observed latent heat flux under dry canopy conditions and when soil evaporation is negligible. We inverted the McNaughton and Black equation for canopy latent heat flux (McNaughton \& Black, 1973) to estimate bulk canopy conductance, $G_{\mathrm{c}}$ :

$$
G_{\mathrm{c}}=L H \varepsilon \lambda \gamma /\left(\rho C_{\mathrm{p}} v p d\right),
$$

where $L H$ is the measured latent heat flux $\left(\mathrm{W} \mathrm{m}^{-2}\right), \varepsilon$ is the coefficient for the conversion of latent heat to its water equivalent [actual evapotranspiration $\left(E_{\mathrm{a}}\right)$ ], $\lambda$ is the latent heat of vaporisation of water $\left(2270000 \mathrm{~J} \mathrm{~kg}^{-1}\right)$, $\gamma$ is the psychrometric constant $\left(0.66 \mathrm{kPa} \mathrm{K}^{-1}\right), \rho$ is the density of air $\left(\mathrm{kg} \mathrm{m}^{-3}\right), C_{\mathrm{p}}$ is the heat capacity of air $\left(1012 \mathrm{~J} \mathrm{~kg}^{-1} \mathrm{~K}^{-1}\right.$ ), and vpd is the observed vapour pressure deficit $(\mathrm{kPa})$.

Using the estimated bulk canopy conductance to carbon $G_{\mathrm{CCO}_{2}}\left(=G_{\mathrm{c}} / 1.6\right)$, observed rates of net photosynthesis from the eddy-covariance measurements, and atmospheric $\mathrm{CO}_{2}$ concentrations, canopy bulk leaf intercellular $\mathrm{CO}_{2}$ concentration $\left(C_{\mathrm{i}}\right)$ can be calculated 
using the simple supply and demand algorithm

$$
C_{\mathrm{i}}=C_{\mathrm{a}}-\left(A_{\mathrm{n}} / G_{\mathrm{CO}_{2}}\right),
$$

where $C_{\mathrm{a}}\left(\mu \mathrm{mol} \mathrm{mol}^{-1}\right)$ is the atmospheric carbon concentration. As all measurements used in the calculation of bulk conductance have reference above the canopy, boundary layer effects are assumed to be minimal for the calculation of bulk $C_{\mathrm{i}}$.

\section{Data selection}

The analysed FLUXNET data were filtered to consider only daytime values by selecting data corresponding to half hours with photosynthetically active radiation (PAR) of $400 \mu \mathrm{mol} \mathrm{m}^{-2} \mathrm{~s}^{-1}$ or greater, and assimilation rates of greater than $2 \mu \mathrm{molCO} \mathrm{m}^{-2} \mathrm{~s}^{-1}$. Following Harley et al. (1992), only data corresponding to a leaf intercellular carbon concentration of between 100 and $300 \mu \mathrm{mol} \mathrm{mol}^{-1}$ were used in the calculation of mesophyll conductance. Screening was also performed to remove data relating to precipitation events, and extreme temperatures $\left(<5^{\circ}\right.$ or $\left.>35^{\circ}\right)$. Gap filled data were not considered.

\section{Calculating bulk mesophyll conductance and carbon dioxide concentrations in the chloroplast}

The bulk canopy mesophyll conductance, $G_{\mathrm{m}}$, is the canopy scaled equivalent of leaf internal conductance $\left(G_{\mathrm{m}}\right)$ from the sub-stomatal cavities to chloroplasts and was estimated according to the variable electron transport rate method of Harley et al. (1992)

$$
\begin{aligned}
G_{\mathrm{m}}= & A_{\mathrm{n}} /\left(C_{\mathrm{i}}-\Gamma^{*}\left(J+8\left(A_{\mathrm{n}}+R_{\mathrm{d}}\right)\right) /\left(J-4\left(A_{\mathrm{n}}\right.\right.\right. \\
& \left.\left.\left.+R_{\mathrm{d}}\right)\right)\right),
\end{aligned}
$$

where $C_{\mathrm{i}}$ is the bulk canopy leaf intercellular carbon concentration and $A_{\mathrm{n}}$ is the net photosynthetic assimilation rate taken from the FLUXNET data. The $\mathrm{CO}_{2}$ compensation point, $\Gamma^{*}$, and the mitochondrial respiration rate, $R_{\mathrm{d}}$, are calculated on a leaf temperature basis using an Arrhenius-type equation (Bernacchi et al., 2002). The canopy average electron transport rate, $J$, was estimated for each site through the calibration of a two-leaf (sun-shade) canopy photosynthetic model (Farquhar et al., 1980; De Pury \& Farquhar, 1997; Wang \& Leuning, 1998; Dai et al., 2004; but see Keenan et al., 2009b), coupled to a canopy distribution model which divides the canopy into sunlit and shaded leaves, with the amount of intercepted diffuse and direct radiation depending on the time of the day, season, and the area of leaf exposed to the sun (Campbell, 1986). J depends on the maximal electron transport rate $\left(J_{\max }\right)$ and the PAR absorbed by photosystem II $\left(\mathrm{PAR}_{\mathrm{PS} 2}\right)$, (De Pury \& Farquhar, 1997), as the minimal solution to

$$
\theta J^{2}-\left(\mathrm{PAR}_{P S 2}+J_{\max }\right) J+\mathrm{PAR}_{P S 2} J_{\max }=0,
$$

where $\theta$ is a curvature parameter. $J_{\max }$ is calculated independently for each site, using a maximal reference value $J_{\max 25}$ estimated through the calibrating of the Farquhar et al. (1980) photosynthesis model to the hourly flux data at each site (see Keenan et al., 2009b), and an Arrhenius-type response based on leaf temperature (Medlyn et al., 2002). Leaf temperature is dependent on the energy balance of the leaf. It was estimated for both sunlit and shaded leaves for each site using the two-leaf canopy photosynthetic model (Farquhar et al., 1980; De Pury \& Farquhar, 1997; Wang \& Leuning, 1998; Dai et al., 2004; but see Keenan et al., 2009b) which calculates leaf temperature by using numerical iteration to close the energy balance equations (coupling climate variables, assimilation, and conductance). No direct temperature effect was applied to the Harley approach, as the effect of temperature on mesophyll conductance is unresolved, with both positive and negative responses reported in the literature (Bernacchi et al., 2002; Pons \& Welschen, 2003; Niinemets et al., 2009b). Cuticular conductance is assumed to have no significant effect on calculations for the range of species and data selected.

Bulk canopy $C_{\mathrm{c}}$ is then a function of the net photosynthesis assimilation rate, bulk canopy conductance to carbon, $G_{\mathrm{CCO}_{2}}$, and bulk canopy mesophyll conductance, $G_{\mathrm{m}}$

$$
C_{\mathrm{c}}=C_{\mathrm{a}}-\left(A_{\mathrm{n}} / G_{\mathrm{CCO}_{2}}\right)-\left(A_{\mathrm{n}} / G_{\mathrm{m}}\right) .
$$

\section{Quantitative limitation analysis}

Using quantitative limitation analysis, it is possible to calculate the limitations imposed on photosynthesis by stomatal conductance $\left(\mathrm{SC}_{\mathrm{L}}\right)$, mesophyll conductance $\left(\mathrm{MC}_{\mathrm{L}}\right)$, or biochemical processes $\left(B_{\mathrm{L}}\right)$ at any time of the year, assuming a reference maximum is available. The filtered data were used to separate the three different limitations on maximum photosynthesis, following Grassi \& Magnani's (2005) elaboration of Jones (1985). Thus the response of each limitation to changes in soil water availability could be observed.

This approach makes it possible to compare absolute or relative limitations to assimilation over any period of time. The analysis partitions photosynthesis limitations into components related to stomatal conductance, mesophyll conductance, and leaf biochemical characteristics (assuming that a reference maximum assimilation rate can be defined as a standard). Lightsaturated photosynthesis is generally limited by substrate availability and can be expressed as (Farquhar 
et al., 1980)

$$
A_{\mathrm{n}}=\frac{V c_{\max } C_{\mathrm{c}}}{\left(C_{\mathrm{c}}+K_{\mathrm{c}}\left(1+O /\left(K_{\mathrm{O}}\right)\right)\right)}\left(1+\frac{\Gamma^{*}}{C_{\mathrm{c}}}\right)-R_{\mathrm{d}},
$$

where $K_{\mathrm{c}}$ and $K_{\mathrm{o}}$ are the Michaelis-Menten constants for $\mathrm{CO}_{2}$ and $\mathrm{O}_{2}$, and $\mathrm{O}$ is atmospheric $\mathrm{O}_{2}$ concentration. At the canopy level, this assumes that the canopy is limited by $V c_{\max }$, which is not always the case. We assumed canopy $V c_{\max }$ limitation during mid-day hours, and used only data points with a $C_{i}$ value of less than $300 \mu \mathrm{mol} \mathrm{mol}^{-1}$. A change in leaf assimilation can be then expressed in terms of the relative changes in $V c_{\max }$ and $C_{\mathrm{c}}$ as

$$
\mathrm{d} A_{\mathrm{n}}=\frac{\delta A_{\mathrm{n}}}{\delta C_{\mathrm{c}}} \mathrm{d} C_{\mathrm{c}}+\frac{\delta A_{\mathrm{n}}}{\delta V c_{\max }} \mathrm{d} V c_{\max }
$$

With $C_{\mathrm{c}}$ calculated as in Eqn (5), changes in $C_{\mathrm{c}}$ can then be expressed as

$$
\begin{aligned}
\mathrm{d} C_{\mathrm{c}}= & \frac{A_{\mathrm{n}}}{G_{\mathrm{COO}_{2}}} \frac{\mathrm{d} G_{\mathrm{COO}_{2}}}{G_{\mathrm{CCO}_{2}}}+\frac{A_{\mathrm{n}}}{G_{\mathrm{m}}} \frac{\mathrm{d} G_{\mathrm{m}}}{G_{\mathrm{m}}} \\
& -\left(\frac{1}{G_{\mathrm{COO}_{2}}}+\frac{1}{G_{\mathrm{m}}}\right) \mathrm{d} A_{\mathrm{n}} .
\end{aligned}
$$

From Eqn (6) the sensitivity of assimilation to carboxylation potential can be finally expressed as

$$
\frac{\delta A_{\mathrm{n}}}{\delta A_{\max }}=\frac{A_{\mathrm{n}}}{V c_{\max }} .
$$

Relative changes in light-saturated assimilation can then be expressed in terms of parallel relative changes in $G_{c}$ and $G_{m}$ and in biochemical capacity (i.e., in maximum carboxylation rate) by substituting Eqns (8) and (9) into Eqn (7)

$$
\begin{aligned}
\mathrm{d} A / A= & S C_{\mathrm{L}}+M C_{\mathrm{L}}+B_{\mathrm{L}} \\
= & l_{\mathrm{s}} \frac{\mathrm{d} G_{\mathrm{CCO}_{2}}}{G_{\mathrm{cCO}_{2}}}+l_{\mathrm{m}} \frac{\mathrm{d} G_{\mathrm{m}}}{G_{\mathrm{m}}}+l_{\mathrm{b}} \frac{\mathrm{d} V c_{\max }}{V c_{\max }}, \\
l_{\mathrm{s}} & =\frac{\left(G_{\text {tot }} / G_{\mathrm{CCO}_{2}}\right) \delta A_{\mathrm{n}} / \delta C_{\mathrm{c}}}{G_{\text {tot }}+\delta A_{\mathrm{n}} / \delta C_{\mathrm{c}}}, \\
l_{\mathrm{m}} & =\frac{\left(G_{\text {tot }} / G_{\mathrm{m}}\right) \delta A_{\mathrm{n}} / \delta C_{\mathrm{c}}}{G_{\text {tot }}+\delta A_{\mathrm{n}} / \delta C_{\mathrm{c}}}, \\
l_{\mathrm{b}} & =\frac{G_{\text {tot }}}{G_{\text {tot }}+\delta A_{\mathrm{n}} / \delta C_{\mathrm{c}}},
\end{aligned}
$$

where $G_{\text {tot }}$ is total conductance to $\mathrm{CO}_{2}$ between the leaf surface and carboxylation sites $\left(1 / G_{\text {tot }}=1 / G_{\mathrm{CCO}_{2}}\right.$ $\left.+1 / G_{m}\right), \mathrm{SC}_{\mathrm{L}}, \mathrm{MC}_{\mathrm{L}}$, and $B_{\mathrm{L}}$ are the contributions of stomatal and mesophyll conductance and of maximum carboxylation rate to $\mathrm{d} A / A$, respectively, and $l_{\mathrm{s}}, l_{\mathrm{m}}$, and $l_{\mathrm{b}}$ are the corresponding relative limitations, with value between 0 and 1 . The relative change in lightsaturated assimilation can be defined as the ratio of the actual value of $A_{\max }$ over the maximum value over the season

$$
\frac{\mathrm{d} A_{\mathrm{n}}}{A_{\mathrm{n}}} \approx \frac{A_{\max }^{\mathrm{ref}}-A_{\max }}{A_{\max }^{\mathrm{ref}}} .
$$

Relative changes in $G_{c}$ and $G_{m}$ and $V c_{\max }$ were obtained similarly and used in Eqns (10) and (11). By explicitly considering mesophyll conductance, it is thus possible to partition nonstomatal limitations among the two underlying mechanisms related to $\mathrm{CO}_{2}$ diffusion and carboxylation.

This method of calculating the relative limitations requires knowledge on the photosynthetic Rubisco capacity, $V c_{\max }$. This was estimated in a similar manner to the estimation of $J_{\max }$, using a maximal reference value $V c_{\max 25}$ [with an Arrhenius type response based on leaf temperature (Bernacchi et al., 2001; Medlyn et al., 2002)], and a two-leaf canopy coupled conductancephotosynthesis model calibrated to hourly flux data at each site (Farquhar et al., 1980; Campbell, 1986; Wang \& Leuning, 1998; Dai et al., 2004; but see Keenan et al., $2009 \mathrm{~b})$. No response of $V c_{\max }$ to soil water stress was considered.

\section{Results}

\section{Conductance, assimilation, and carbon concentrations}

The rate of photosynthesis, the concentration of carbon in the chloroplast, and mesophyll conductance, was observed to be intricately linked. Mesophyll conductance was found to have a strong role in the control of carbon available for assimilation in the chloroplast. The imperfect scaling with stomatal conductance followed a logarithmic relationship. Changes in high conductance values had little effect on the concentration of carbon in the chloroplast, while changes at low rates of conductance led to big differences in the available carbon at the site of carboxylation (Fig. 1a).

Large differences in concentration were observed between the $C_{\mathrm{i}}$ and $C_{\mathrm{c}}$ pools for both the $Q$. ilex species at Puechabon and the $Q$. douglasii species at Tonzi during periods of low internal conductance. Maximum mesophyll conductance was comparatively low for both species when compared with the other species included in the study (Fig. 1a). Although Q. ilex is a broadleaf evergreen species, and $Q$. douglasii deciduous, both have very coarse, sclerophyllous, and drought-tolerant leaves. The range of $C_{\mathrm{i}}-C_{\mathrm{c}}$ reached for the two deciduous species at Collelongo and Roccarespampani was 
(a)
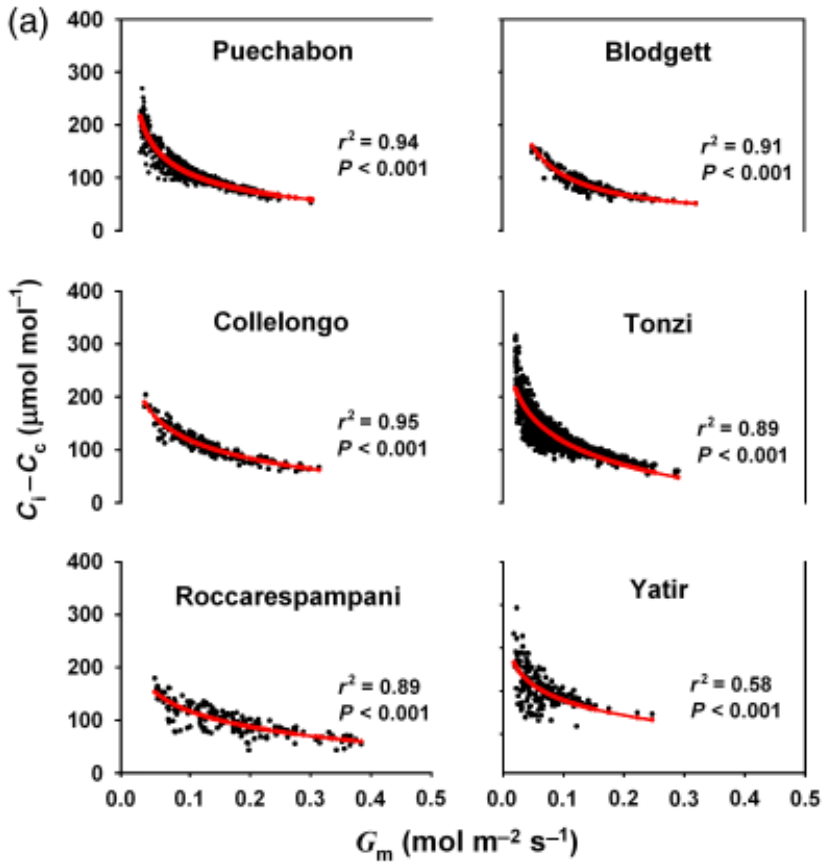

(b)
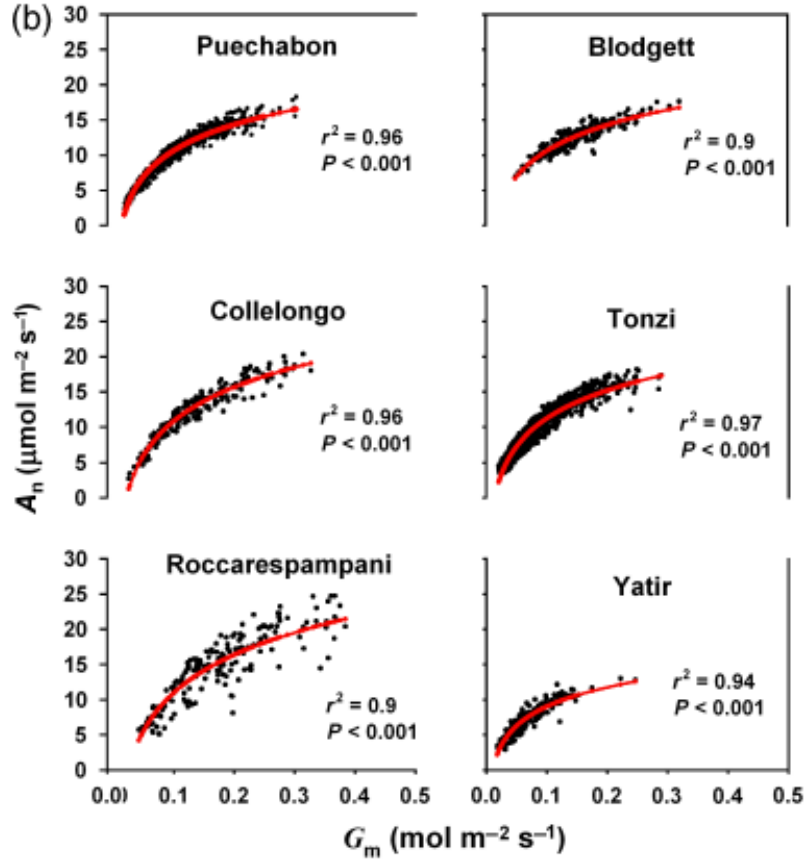

Fig. 1 (a) Bulk canopy mesophyll conductance $\left(G_{\mathrm{m}}, \mathrm{molm}^{-2} \mathrm{~s}^{-1}\right)$ against the drawdown $\left(C_{\mathrm{i}}-C_{\mathrm{c}} \mu \mathrm{mol} \mathrm{mol}^{-1}\right)$ of $\mathrm{CO}_{2}$ from the intercellular spaces to the chloroplast. (b) Bulk canopy mesophyll conductance $\left(G_{\mathrm{m}}, \mathrm{mol} \mathrm{m}^{-2} \mathrm{~s}^{-1}\right)$ against net photosynthesis $\left(A_{\mathrm{n}}\right.$ $\left.\mu \mathrm{mol} \mathrm{m} \mathrm{m}^{-2} \mathrm{~s}^{-1}\right)$, for each of the studied sites. Fitted lines represent the regression $y=a_{0}+a_{1} \log _{10}(x)$ for $n$ data points, where $a_{0}$, and $a_{1}$ are Puechabon $(n=1465)$ (a) -10.91, -119.68 , (b) 13.21, 11.55; Collelongo $(n=185)$ (a) 3.93, 114.55, (b) 9.21, 13.03; Roccarespampani $(n=214)$ (a) 18.9, -97.89, (b) 15.46, 16.84; Blodgett $(n=195)$ (a) -25.52, -132.22, (b) 10.63, 10.95; Tonzi $(n=546)(a)-32.74,-151.05$, (b) 15.11, 14.14; Yatir $(n=78)$ (a) $-18.12,-98.39$, (b) 12.89, 9.94 .

comparatively low, reaching a maximal value of $200 \mu \mathrm{mol} \mathrm{mol}^{-1}$ at low levels of mesophyll conductance. Both demonstrated relatively high levels of mesophyll conductance, reaching $0.4 \mathrm{~mol} \mathrm{~m}^{-2} \mathrm{~s}^{-1}$. Blodgett, by far the wettest site included in the study, showed levels of mesophyll conductance comparable to those observed at Puechabon and Tonzi, but the difference between the two carbon pools was small. At Yatir, the driest site in the study, mesophyll conductance levels were very low, and a strong response of drawdown was observed at low levels of conductance.

The deciduous species at Collelongo and Roccarespampani showed high rates of assimilation and conductance compared to the other sites. The other deciduous species at Tonzi, in comparison, showed much lower rates of both conductance and assimilation. At Blodgett, the wettest site, both assimilation and conductance were observed within a narrower range than at the other sites. The Yatir site showed very low rates of assimilation and conductance. Assimilation levels corresponded closely to the rate of mesophyll conductance at each site, with increased dispersion observed with increasing conductance levels (Fig. 1b).

$A_{\mathrm{n}}-C_{\mathrm{i}}$ curves are used extensively to extract parameters for calculating photosynthesis. Such curves cal- culated on the basis of $C_{\mathrm{c}}$ were much less susceptible to variation (Fig. 2), i.e. $C_{\mathrm{c}}$ is statistically subject to less variation with respect to $A_{\mathrm{n}}$ and demonstrates a stronger response to changes in $A_{\mathrm{n}}$. This suggests that the concentration of carbon in the chloroplast could be a more reliable estimator of assimilation rates than the concentration of carbon in the intercellular spaces in all species. This was equally true to conditions of high water availability as to dry conditions.

\section{Responses to changes in soil water}

The concentration of carbon in the chloroplast was more responsive to changes in soil water content than the intercellular carbon pool at each of the studied sites at low soil water levels (Fig. 3), thus in part explaining the reduced variance associated with using the carbon concentration in the chloroplast as an estimator for the rate of assimilation. As soil water stress set in, the carbon pool in the chloroplast diminished in parallel with the carbon concentration in the intercellular spaces, driven by stomatal closure. As the stress progressed in severity, the role of mesophyll conductance increased, reducing the concentration of carbon in the chloroplast at a faster rate than the reductions of the carbon concentration in the intercellular spaces, 

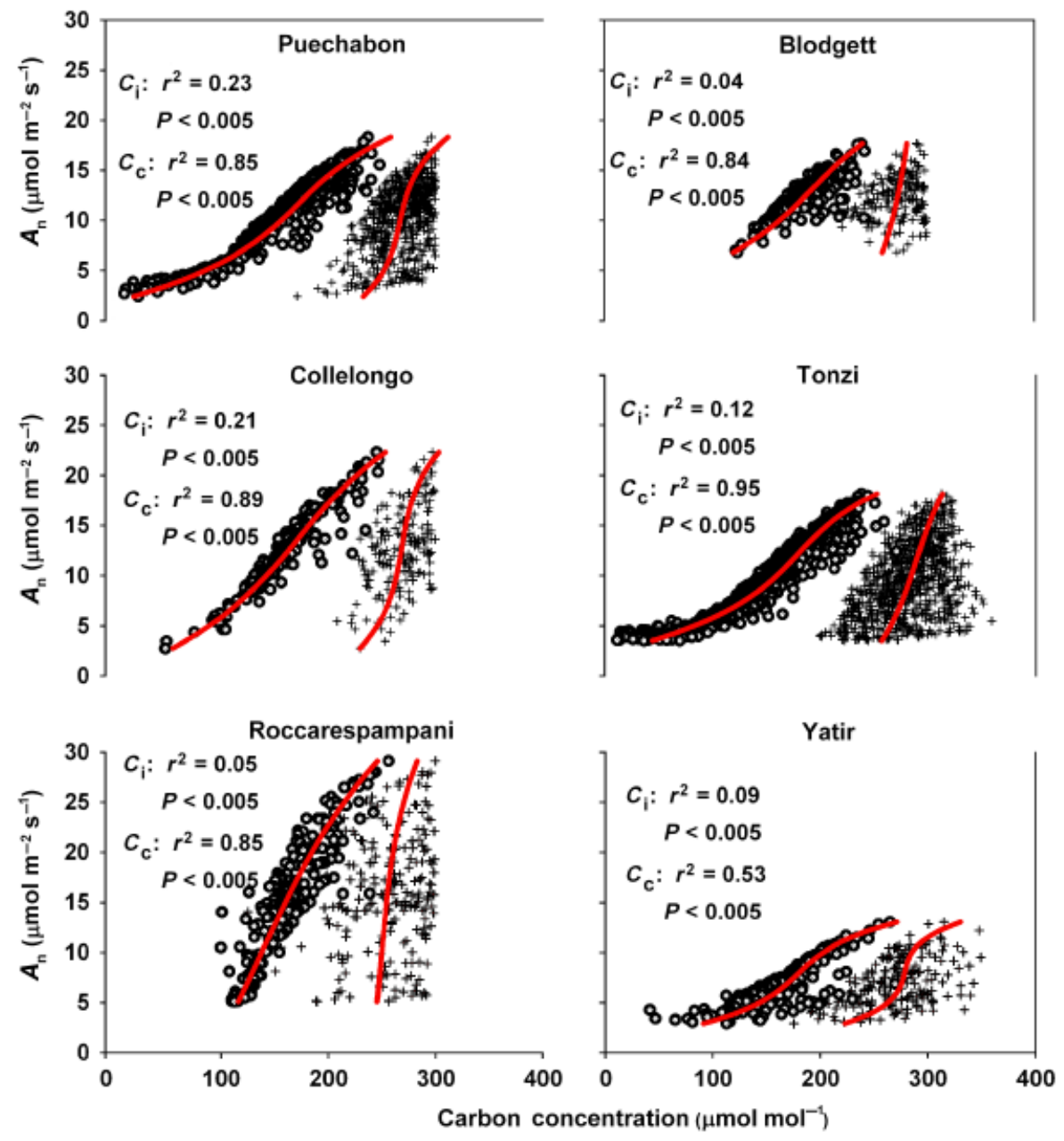

Fig. 2 Rate of bulk canopy assimilated carbon $\left(A_{\mathrm{n}}\right)$ against $\mathrm{CO}_{2}$ concentrations in the leaf intercellular space $\left(\mathrm{O}: C_{\mathrm{i}}, \mu \mathrm{mol} \mathrm{mol}{ }^{-1}\right)$, and the chloroplast $\left(+: C_{\mathrm{c}} \mu \mathrm{mol} \mathrm{mol}^{-1}\right)$, at each of the studied sites. Fitted lines represent the polynomial regression $y=a_{0}+a_{1}(x)+a_{2}\left(x^{2}\right)$ for $n$ data points, where $n=1465$ (Puechabon), 185 (Collelongo), 195 (Blodgett), 214 (Roccarespampani), 546 (Tonzi), 78 (Yatir).

i.e. the stomata responded first, causing a reduction in both carbon pools, and mesophyll conductance decreased with increasing water stress, further limiting the carbon pool in the chloroplast.

The difference between the carbon pools remained steadily constant until a site-specific soil water level is met, at which point mesophyll conductance decreased, limiting the transfer of carbon from the intercellular spaces to the site of carboxylation in the chloroplast (Fig. 4). This is directly related to changes in soil water content and varied between sites and species. That said, a general response was found among all species studied. As the stress progressed in severity, the proportional role of the stomata decreased, while the role of mesophyll conductance became increasingly important in the limiting of assimilation rates. The observed responses were statistically significant at all sites except Yatir (Table 2).

\section{Quantitative limitation analysis}

The effect of changes in soil water content on the response of the relative role of each limitation varied between sites (Fig. 5). Significant relationships between soil water and each limitation were found for all sites, except for biochemical limitations at the Blodgett site (Table 3). The balance between stomatal and mesophyll conductance limitations $\left(\mathrm{SC}_{\mathrm{L}}\right.$ and $\left.\mathrm{MC}_{\mathrm{L}}\right)$ was site dependent, but an increasing role of $\mathrm{MC}_{\mathrm{L}}$ with increased soil water stress was generally observed, with the response of $\mathrm{MC}_{\mathrm{L}}$ reaching or surpassing that of $\mathrm{SC}_{\mathrm{L}}$ at all sites except the Collelongo site. The species at Collelongo is the deciduous $F$. sylvatica, which is the only nontypical Mediterranean species included in the study. Of the remaining species the response of $\mathrm{MC}_{\mathrm{L}}$ was strongest in three ( $Q$. ilex, $Q$. cerris and P. halepensis). The response of $\mathrm{SC}_{\mathrm{L}}$ was of a similar magnitude to that of $\mathrm{MC}_{\mathrm{L}}$ for two 

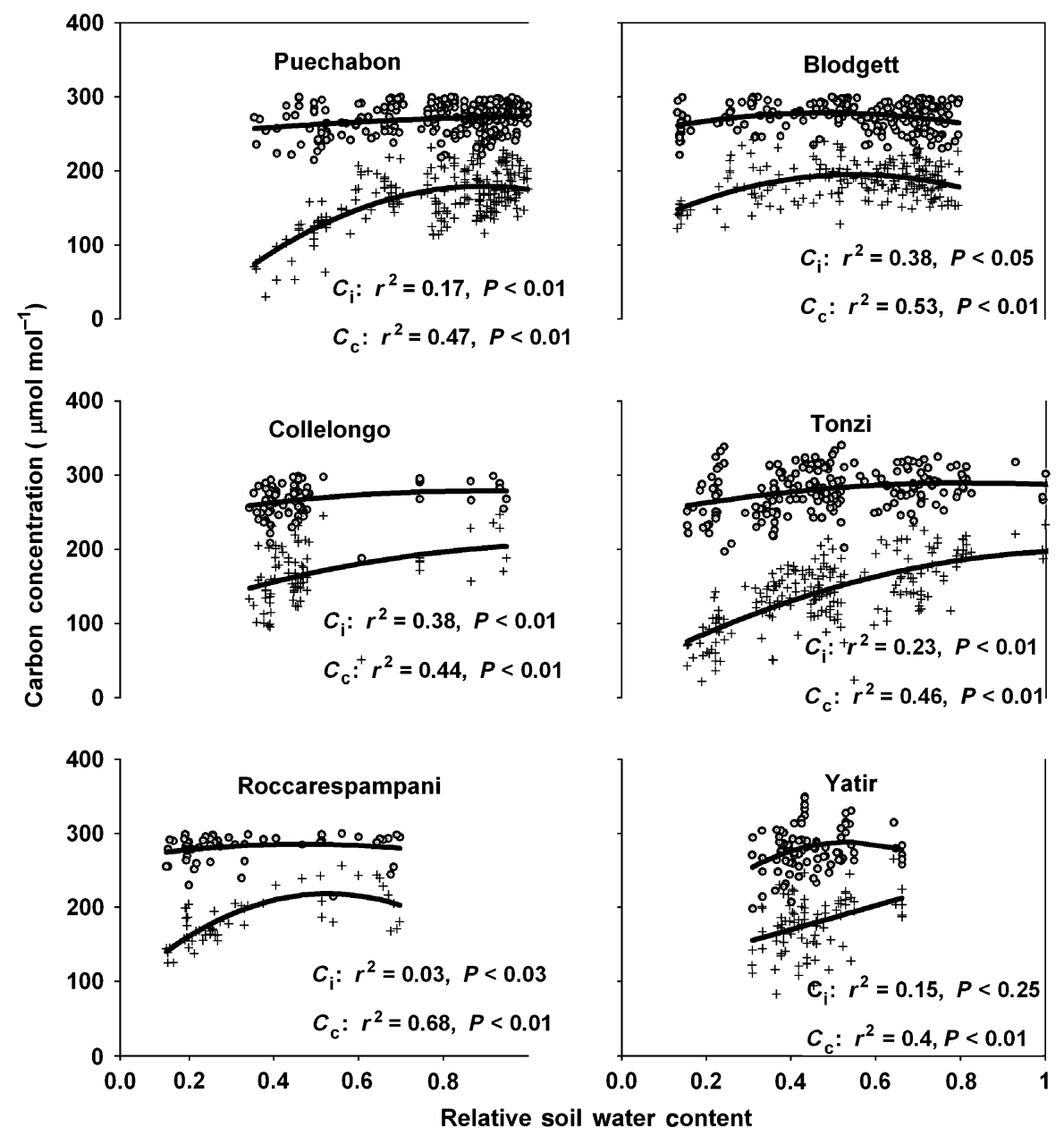

Fig. 3 The response of concentrations of $\mathrm{CO}_{2}$ in the leaf intercellular spaces $\left(\mathrm{O}: C_{\mathrm{i}}, \mu \mathrm{mol} \mathrm{mol}^{-1}\right)$ and in the chloroplast $\left(+: C_{\mathrm{c}}\right.$ $\mu \mathrm{mol} \mathrm{mol}^{-1}$ ) to changes in the available relative soil water content (RSWC - total soil water content relative to its maximum) for each site. Fitted lines represent the polynomial regression $y=a_{0}+a_{1}(x)+a_{2}\left(x^{2}\right)$ for $n$ mid-day data points, where $n=235$ (Puechabon), 120 (Collelongo), 130 (Blodgett), 54 (Roccarespampani), 267 (Tonzi), 64 (Yatir).

species (P. ponderosa, Q. douglasii). The role of the biochemical limitation $\left(B_{\mathrm{L}}\right)$ decreases steadily during the season at each site.

\section{Discussion}

\section{Conductance and internal carbon dynamics}

The finite internal conductance observed in all species results in a significant decrease in $\mathrm{CO}_{2}$ concentrations from $C_{i}$ to $C_{c}$, imposing a large limitation on photosynthesis. This supports suggestions that mesophyll conductance plays a big role in the control of photosynthesis, and may decrease rapidly after the onset of water stress (e.g., Centritto et al., 2003; Flexas et al., 2008; Niinemets et al., 2009b). Measurements in the literature are scarce, but the values reported here compare well against available data. The $C_{\mathrm{c}}$ values reported here for optimal assimilation conditions (high $A_{\mathrm{n}}$ ) for Q. ilex and F. sylvatica fall within values published for these species in a recent literature review (Warren \& Adams, 2006; Warren et al., 2007). No published values could be found for the other species included in the study.

Results here show that photosynthesis and the internal carbon dynamics of the leaf are not largely affected by changes in mesophyll conductance when conductance is high. As both mesophyll conductance and the rate of carbon assimilation control the concentration of carbon in the chloroplast, which in turn limits the rate of photosynthesis, a response is observed in the relation between mesophyll conductance and assimilation rates at lower conductance rates (Fig. 1b), with little difference resulting in changes of mesophyll conductance above $0.2-0.3 \mathrm{~mol} \mathrm{~m}^{-2} \mathrm{~s}^{-1}$, and large changes below. The threshold observed here highlights the sensitivity of the rate of photosynthesis to the concentration of 

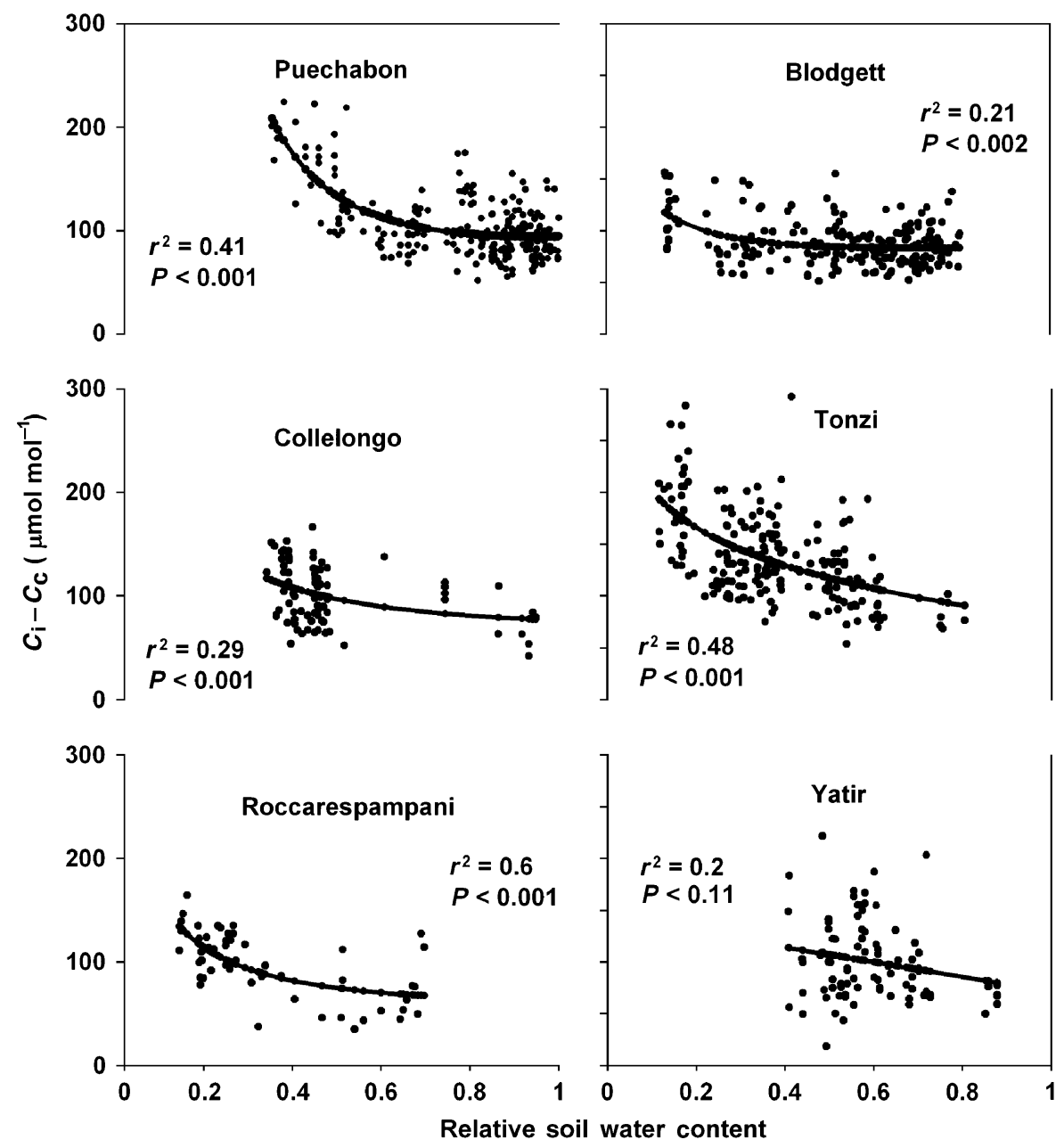

Fig. 4 The $\mathrm{CO}_{2}$ concentration gradient between the leaf intercellular spaces and the chloroplast $\left(C_{\mathrm{i}}-C_{\mathrm{c}}, \mu \mathrm{mol}\right.$ mol $\left.{ }^{-1}\right)$ against changes in the relative soil water content (RSWC - total soil water content relative to its maximum) at each site. Fitted lines represent the polynomial regression $y=a_{0}+a_{1}(x)+a_{2}\left(x^{2}\right)$ for $n$ midday data points, where $n=235$ (Puechabon), 120 (Collelongo), 130 (Blodgett), 54 (Roccarespampani), 267 (Tonzi), 64 (Yatir).

Table 2 Drawdown $\left(C_{i}-C_{c}, \mu \mathrm{mol} \mathrm{mol}{ }^{-1}\right)$ from the intercellular spaces to the sites of carboxylation, and bulk canopy mesophyll conductance $\left(G_{\mathrm{m}}, \mathrm{mol} \mathrm{m}^{-2} \mathrm{~s}^{-1}\right)$ in the species studied under different soil water availabilities

\begin{tabular}{llllll}
\hline & \multicolumn{2}{l}{$C_{\mathrm{i}}-C_{\mathrm{c}}$ range $\left(\mu \mathrm{mol} \mathrm{mol}^{-1}\right)$} & & & \multicolumn{2}{c}{$\mathrm{G}_{\mathrm{m} \text { range }\left(\mathrm{mol} \mathrm{m}^{-2} \mathrm{~s}^{-1}\right)}$} \\
\cline { 2 - 3 } Species & High soil water & Low soil water & & High soil water & Low soil water \\
\hline Quercus ilex & $57-101$ & $112-218$ & $0.054-0.21$ & $0.014-0.072$ \\
Quercus douslasii & $69-94$ & $98-271$ & $0.13-0.24$ & $0.023-0.047$ \\
Quercus cerris & $42-104$ & $74-164$ & $0.19-0.38$ & $0.03-0.072$ \\
Pinus halepensis & $56-119$ & $61-211$ & $0.05-0.12$ & $0.02-0.08$ \\
Pinus ponderosa & $53-77$ & $56-148$ & $0.11-0.23$ & $0.06-0.12$ \\
Fagus sylvatica & $34-54$ & $52-168$ & $0.12-0.34$ & $0.015-0.17$ \\
\hline
\end{tabular}

High soil water: $>0.65$; Low soil water: lowest $10 \%$ reached.

carbon available for assimilation. The tight coupling between the rate of photosynthesis, the concentration of carbon in the chloroplast, and mesophyll conductance shows the potential importance of mesophyll conductance in the control of photosynthesis. It is important to note that this close correlation could in part be explained by the larger role given to $A_{\mathrm{n}}$ in the calculation of $C_{\mathrm{c}}$, when compared with the role of $A_{\mathrm{n}}$ 

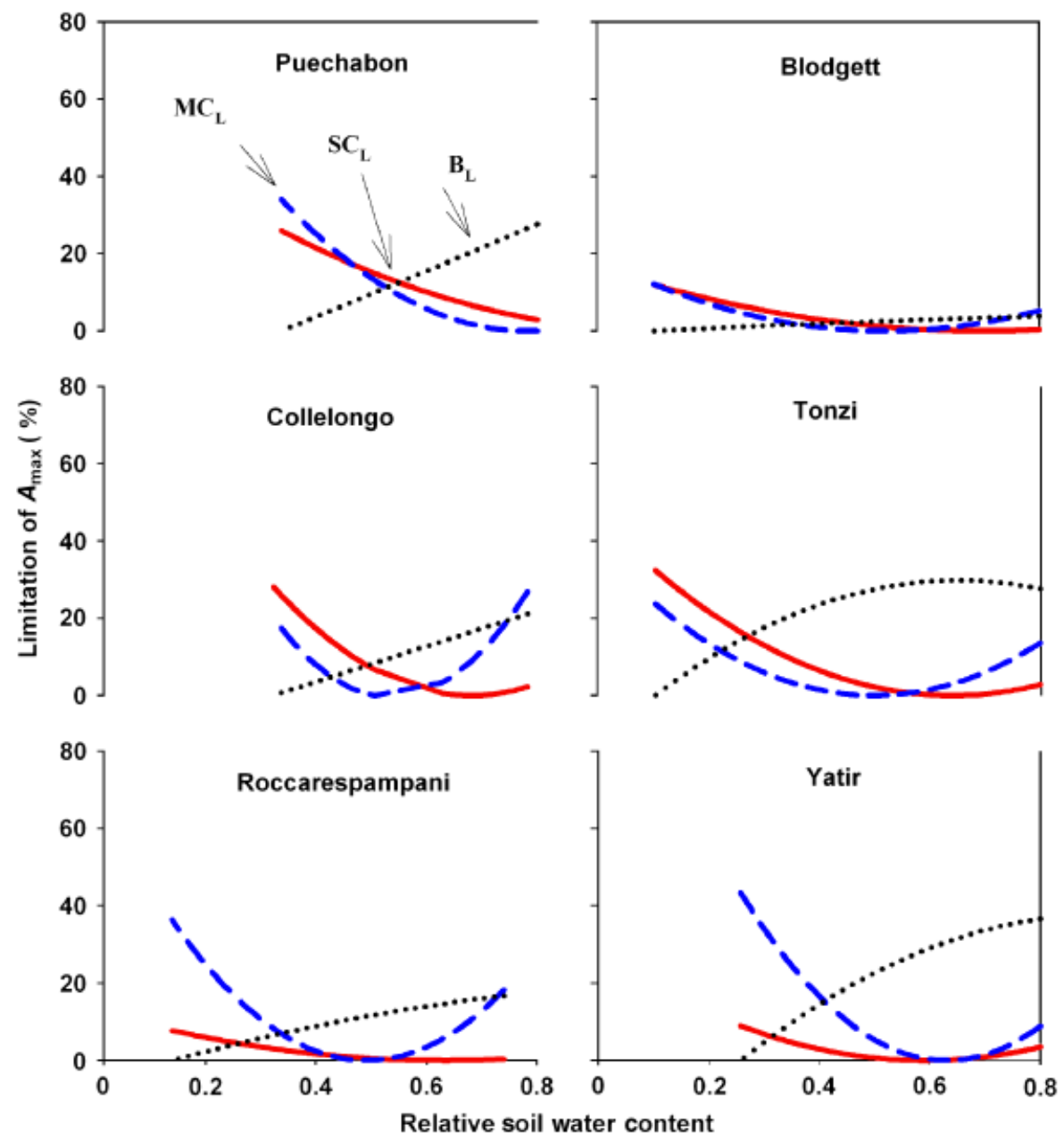

Fig. 5 Regressions of results from the analysis of independent limitations of photosynthesis at each site, over an available soil water gradient (data not shown), relative to their minimum limitation (with nongrowth periods excluded). Limitations are (1) stomatal limitation (red solid line, $\mathrm{SC}_{\mathrm{L}}$ ), (2) mesophyll conductance limitation (blue dashed line, $\mathrm{MC}_{\mathrm{L}}$ ), (3) biochemical limitation (black dotted line, $B_{\mathrm{L}}$ ). Relative soil water content (RSWC) is the total soil water content relative to its maximum.

Table 3 Statistics associated with the regressions of Fig. 5

\begin{tabular}{|c|c|c|c|c|c|c|c|c|c|c|c|c|}
\hline \multirow[b]{2}{*}{$y=a_{0}+a_{1}(x)+a_{2}\left(x^{2}\right)$} & \multicolumn{2}{|c|}{ Puechabon } & \multicolumn{2}{|c|}{ Collelongo } & \multicolumn{2}{|c|}{ Rocca } & \multicolumn{2}{|c|}{ Blodgett } & \multicolumn{2}{|c|}{ Tonzi } & \multicolumn{2}{|c|}{ Yatir } \\
\hline & $r^{2}$ & $P$ & $r^{2}$ & $P$ & $r^{2}$ & $P$ & $r^{2}$ & $P$ & $r^{2}$ & $P$ & $r^{2}$ & $P$ \\
\hline$S_{\mathrm{L}}$ & 0.62 & $<0.01$ & 0.57 & $<0.01$ & 0.11 & $<0.03$ & 0.27 & $<0.01$ & 0.71 & $<0.01$ & 0.25 & $<0.01$ \\
\hline $\mathrm{MC}_{\mathrm{L}}$ & 0.37 & $<0.01$ & 0.22 & $<0.01$ & 0.50 & $<0.01$ & 0.38 & $<0.01$ & 0.34 & $<0.01$ & 0.57 & $<0.01$ \\
\hline$B_{\mathrm{L}}$ & 0.67 & $<0.01$ & 0.66 & $<0.01$ & 0.36 & $<0.01$ & 0.13 & $<0.40$ & 0.67 & $<0.01$ & 0.70 & $<0.01$ \\
\hline$N$ & & 1465 & & 185 & & 214 & & 195 & & 546 & & 78 \\
\hline
\end{tabular}

in the calculation of $C_{\mathrm{i}}$. There is, as yet, no $A_{\mathrm{n}}$ independent method by which to estimate $G_{m}$, thus such a problem is currently common to all studies of stomatal and mesophyll conductance. We cannot conclude, therefore, that $C_{\mathrm{c}}$ is a better estimator of $A_{\mathrm{n}}$, until an independent method of estimating $G_{\mathrm{m}}$ is developed.

Similar responses of drawdown to changes in mesophyll conductance were observed in the deciduous species at Collelongo and Roccarespampani, with each showing large gradual responses to changes in mesophyll conductance (Fig. 1a), possibly reflecting structural characteristics of deciduous leaves. This was not observed at the deciduous species, $Q$. douglasii at Tonzi, however, though Tonzi receives almost half the rainfall than Collelongo and 50\% less than falls in Roccarespampani, leading to high levels of water stress and 
lower conductance. $Q$. douglasii leaves have a low metabolic rate, are very coarse and well structured, thus possibly limiting internal diffusion. The response observed for $Q$. douglasii was similar to that of the broadleaf evergreen species $Q$. ilex at Puechabon, possibly reflecting similar leaf structural characteristics [leaf dry mass per area: $Q$. douglasii $\approx 165 \mathrm{~g} \mathrm{~m}^{-2}$; Q. ilex $\approx 185 \mathrm{~g} \mathrm{~m}^{-2}(\mathrm{Xu} \&$ Baldocchi, 2003;)Keenan et al., 2009a]. This response was less noticeable for the needle leaf evergreen species $P$. ponderosa (leaf dry mass per area $\approx 250 \mathrm{~g} \mathrm{~m}^{-2}$ ) at Blodgett, possibly due to the large quantity of rainfall and high soil water availability. The real determinants of differences in mesophyll conductance are, however, as yet unknown, though it has been suggested that leaf anatomy, morphology, and biochemical factors are all involved (Warren, 2008b; Niinemets et al., 2009a).

The finding that $C_{\mathrm{i}}-C_{\mathrm{c}}$ varies between species and as a function of available soil water goes against some other previous studies (von Caemmerer \& Evans, 1991; Evans, 1999; Evans \& Loreto, 2000). These studies solely considered response curves of assimilation against mesophyll conductance with few limited data sets. The analysis here included the response of the concentration of $\mathrm{CO}_{2}$ in the chloroplast, and with an extremely large data set, highlights the imperfect scaling of assimilation with mesophyll conductance and demonstrates that different magnitudes of species- or site-dependent responses are possible.

The data presented here does not give the full range of carbon concentrations normally encountered in leaf measurements due to filtering imposed to assure the reliability of the calculated variables, and thus the regressions are not intended as model $A_{\mathrm{n}}-C$ curves. This is aggravated by the large amount of scatter and the low correlation values observed, due the fact that we are looking at the effect of a large scale slow changing process (soil water content), on a fine scale process with a very fast dynamic (carbon pools), using observations taken from above the canopy. The range of values (e.g., those reported in Table 2), for drawdown and mesophyll conductance is therefore larger than normally encountered with leaf level measurements.

However, the results qualitatively show that carbon in the chloroplast potentially exerts a greater control over photosynthesis than carbon in the intercellular spaces. This is possibly due to the fact that it is the carbon in the chloroplast, which is used for assimilation purposes, and thus variance in the relation between carbon concentration and assimilation rates is reduced by using the concentration of carbon in the chloroplast instead of intercellular carbon concentrations. Hence, much of the error associated with the use of $A_{\mathrm{n}}-C_{\mathrm{i}}$ curves can be explained by variations in mesophyll conductance.

\section{Limitations}

The debate over the relative roles of stomatal conductance, mesophyll conductance, and biochemical processes in the limitation of photosynthesis continues, with several studies favouring one or the other control mechanism (stomatal: Cornic et al., 1989; Sharkey, 1990; mesophyll: Warren \& Adams, 2006; Galmes et al., 2007; biochemical: Wilson et al., 2000; Xu \& Baldocchi, 2003). Here we have demonstrated that mesophyll conductance reacts strongly to water stress as in previous studies (Flexas et al., 2002; Warren et al., 2004). Both the loss of turgor (Cornic et al., 1989; Renou et al., 1990), and the activity of aquaporins (Terashima \& Ono, 2002; Kaldenhoff et al., 2008; Miyazawa et al., 2008) have been highlighted as possible mechanisms behind this decline in mesophyll conductance. The magnitude of this reaction to water stress was shown to vary between sites, with no clear signal of a general tendency of either stomatal or mesophyll conductance dominance over photosynthetic reactions to water stress. This study was not capable of ending the debate, but showed that a variety of responses is possible, with $\mathrm{SC}_{\mathrm{L}}$ or $\mathrm{MC}_{\mathrm{L}}$ both capable of responding strongly to water stress in different species under the same analytical methodology. In Puéchabon, Roccarespampani, and Yatir, the response of mesophyll conductance to water stress is stronger than that of stomatal conductance at low soil water levels. The contribution of $\mathrm{SC}_{\mathrm{L}}$ at low soil water availability was strongest at Collelongo, Blodgett, and Tonzi. This may be due to the amount of soil water stress experienced, with Puéchabon, Roccarespampani, and Yatir characteristically encountering more water stress, thus invoking stronger $\mathrm{MC}_{\mathrm{L}}$.

There is no clear understanding of the processes responsible for $B_{\mathrm{L}}$, with many different possibilities highlighted in the literature. Particular attention has been paid to stress-induced leaf senescence (Kramer, 1983), inhibition due to high temperatures (Haldimann \& Feller, 2004), denitrogenisation (Grassi \& Magnani, 2005), enzyme deactivation (Tezara et al., 1999; Lawlor \& Cornic, 2002), activity of aquaporins (Flexas et al., 2004; Kaldenhoff et al., 2008; Miyazawa et al., 2008) among many other possible mechanisms (Kaiser, 1987; Chaves et al., 2002; Lawlor \& Cornic, 2002; Bota et al., 2004). By assuming no stress effect on $V c_{\max }$ we explicitly omit the possibility of $B_{\mathrm{L}}$ due to water stress changes in carboxylation capacity in our analysis, and focus on the balance between the two conductance limitations. Limited data are available on the response of $V c_{\max }$ to water stress, and that which is available has 
not taken into account the effect of a variable mesophyll conductance. The inclusion of a stress induced reduction in $V c_{\max }$ proportionally reduces the role of both $\mathrm{SC}_{\mathrm{L}}$ and $\mathrm{MC}_{\mathrm{L}}$, and has been demonstrated to be sufficient for modelling the stress response of carbon and water fluxes (Reichstein et al., 2003; Keenan et al., $2009 \mathrm{~b})$. With higher $B_{\mathrm{L}}, \mathrm{SC}_{\mathrm{L}}$, and $\mathrm{MC}_{\mathrm{L}}$ would decrease in parallel (Grassi \& Magnani, 2005), but the $\mathrm{SC}_{\mathrm{L}}: \mathrm{MC}_{\mathrm{L}}$ ratio reported here would not change. More field measurements of $V c_{\max }$, together with measurements of mesophyll conductance, are needed to fully understand the processes involved and their role under increasing stress levels.

The parabolic nature of the responses reflects the fact that other factors such as phenology and leaf development could not be separated from the soil water effect. This response, however, compares well with that reported in Grassi \& Magnani (2005, fig. 6), although presented here in a different format. The relative limitations reported here are similar to those reported for other tree species (e.g., Epron et al., 1995; Warren et al., $2003,2004)$ and underline the fact that internal conductance constitutes a large limitation on $\mathrm{CO}_{2}$ fixation. The presented results suggest that mesophyll conductance may be more limiting for photosynthesis than stomatal conductance in water-stressed regions. This is consistent with a predominant role of metabolic rather than structural determinants of mesophyll conductance, such as aquaporins (Flexas et al., 2006). The inclusion of mesophyll conductance in process-based models of terrestrial vegetation may therefore improve our ability to model regional carbon and water fluxes, particularly in regions which suffer seasonal water stress (Ethier \& Livingston, 2004; Niinemets et al., 2009b) or are likely to do so under future projected climate change.

\section{Methodological considerations}

The presented work makes several assumptions regarding possible influencing factors, which could not be quantified from the available data. It was first necessary to assume neither stomatal patchiness nor cuticular conductance have a significant effect when making calculations which average over the whole canopy. It has been reported that, in leaf level experiments, stomatal patchiness may invalidate leaf internal carbon calculations, in particular in drought conditions (Buckley et al., 1997; Mott \& Buckley, 2000). Other more recent studies, however, have shown that the influence of stomatal patchiness over calculations of internal carbon do not carry so much weight as had been earlier reported (Lawlor \& Cornic, 2002). Also, it has been reported that the effect of stomatal patchiness is not as large in the field as it is in laboratory experiments, due to the slow time scale of the onset of drought (Gunasekera \& Berkowitz, 1992).

The procedure used to estimate the electron transport rate through the closure of the canopy energy budget by numerical iteration could generate inaccuracies. In particular, it has been suggested that the electron transport rate is negatively affected by water stress (Sharkey \& Badger, 1982; Flexas et al., 1999), though the results were not transferable to field studies and were only significant at extremely low soil water potentials. It has been shown that even a large overestimation by $50 \%$ in the electron transport rate results in at most a $4-8 \%$ underestimation of $G_{\mathrm{m}}$ (Niinemets et al., 2006) and the degree of underestimation was larger for higher values of internal diffusion conductance, that is, for a situation where a large difference in internal diffusion has a small effect on the concentration of carbon in the chloroplast. This agrees with previous evidence demonstrating that the sensitivity of $G_{m}$ to minor errors in gas exchange and fluorescence measurements increases with increasing $G_{\mathrm{m}}$ (Harley et al., 1992; Ethier \& Livingston, 2004). The larger scatter observable between in the values of response variables at higher $G_{\mathrm{m}}$ values in our study further supports this. Therefore, the determination of $G_{\mathrm{m}}$ for species with inherently low internal conductance such as the Mediterranean species studied here is concluded to be robust against small deviations in the estimation of the electron transport system (Harley et al., 1992; Niinemets et al., 2006). We tested this robustness by reducing $J_{\max }$ in proportion to soil water levels and comparing the resulting mesophyll conductance levels with those reported above. This led, on average, to an $11 \%$ reduction in the estimated mesophyll conductance during periods of high water stress, but did not change the qualitative nature of the responses shown. The presence of alternative electron sinks may underestimate the rate of internal conductance. However, a lack of alternative electron sinks has been demonstrated over a large temperature gradient (Badger et al., 2000).

We assumed in this study that all flux measurements were attributed to the dominant species at each site. This is not always the case, as other tree species on the site, or an active understory, could potentially make large contributions to the total measured fluxes. Little information is available on the flux contribution of different species in mixed forests or for forest understories in the FLUXNET network. For this reason, we focused on highly monospecific stands, and excluded sites at which strong contributions from understory activity had been reported. Data from outside of the growth-period were also excluded. This can not guarantee, however, that the results are unaffected by the presence of nondominant species, and it should be 
noted that the greatest benefit of FLUXNET data is in evaluating process representations, rather than in providing an unbiased estimate of net $\mathrm{CO}_{2}$ exchange (Friend et al., 2007).

\section{Conclusions}

It is as yet unclear as to what processes drive the response of global photosynthesis to drought conditions. Here, we have used a 'scale-down embedded in scale-up' approach (Root \& Schneider, 1995; Rambal et al., 2003), to understand the driving processes behind drought imposed changes in forest carbon and water fluxes. The results of this study highlight the importance of mesophyll conductance in the control of terrestrial vegetation productivity, both in well-watered conditions and in response to soil water stress. The concentration of carbon in the chloroplast was shown to potentially be a more reliable estimator of assimilation rates than the intercellular carbon concentration. This is of importance when modelling photosynthetic rates, both in well-watered and dry conditions. A strong response of mesophyll conductance to soil water stress was observed at all sites. A complex dynamic was observed at each site between the responses of stomatal and mesophyll conductance limitations to photosynthesis. These results have important implications for regional canopy-level photosynthesis modelling, and may explain the some of the difficulties ecosystem models encounter when modelling carbon and water fluxes in Mediterranean conditions. This could be of particular importance in the estimation of Mediterranean primary production, both in current day conditions and when modelling responses to projected future climate change.

\section{Acknowledgements}

This study was funded through GREENCYCLES, the MarieCurie Biogeochemistry and Climate Change Research and Training Network (MRTN-CT-2004-512464) supported by the European Commissions Sixth Framework program. T. K. also acknowledges further support from the CCTAME (Climate Change - Terrestrial Adaptation and Mitigation in Europe, FP7 212535) project, the Consolider-Montes project (CSD2008-00040), and INIA (SUM2006-00020-C02-01). The authors would like to thank and highly commend the FLUXNET coordinator Dennis Baldocchi and all the FLUXNET investigators whose data has contributed to the work discussed here. We also thank Andrew Friend, Sönke Zaehle, Serge Rambal, Ülo Niinemets, and Jaume Flexas for their helpful comments on the manuscript.

\section{References}

Allard V, Ourcival JM, Rambal S, Joffre R, Rocheteau A (2008) Seasonal and annual variation of carbon exchange in an ever- green Mediterranean forest in southern France. Global Change Biology, 14, 714-725.

Badger MR, Von Caemmerer S, Ruuska S, Nakano H (2000) Electron flow to oxygen in higher plants and algae: rates and control of direct photo-reduction (Mehler reaction) and Rubisco activity. Philosophical Transactions of the Royal Society B: Biological Sciences, 355, 1433-1446.

Baldocchi DD, Xu L, Kiang N (2004) How plant functional-type, weather, seasonal drought, and soil physical properties alter water and energy fluxes of an oak-grass savanna and an annual grassland. Agricultural and Forest Meteorology, 123, 13-39.

Beniston M, Stephenson DB, Christensen OB et al. (2007) Future extreme events in European climate: an exploration of regional climate model projections. Climatic Change, 81, 71-95.

Bernacchi CJ, Portis AR Jr, Nakano H, von Caemmerer S, Long SP (2002) Temperature response of mesophyll conductance. Implications for the determination of Rubisco enzyme kinetic sand for limitations to photosynthesis in vivo. Plant Physiology, 130, 1992-1998.

Bernacchi CJ, Singsaas EL, Pimentel C, Portis AR Jr, Long SP (2001) Improved temperature response functions for models of Rubisco-limited photosynthesis. Plant, Cell and Environment, 24, 253-259.

Bota J, Medrano H, Flexas J (2004) Is photosynthesis limited by decreasing rubrisco activity and RuBP content under progressive water stress? New Phytologist, 162, 671-681.

Boyer JS (1982) Plant productivity and environment. Science, 218, 443-448.

Buckley TN, Farquhar GD, Mott KA (1997) Quantitative effects of patchy stomatal conductance distribution features on gasexchange calculations. Plant, Cell and Environment, 20, 867-880.

Campbell GS (1986) Extinction coefficients for radiation in plant canopies calculated using an ellipsoidal inclination angle distribution. Agricultural and Forest Meteorology, 36, 317-321.

Carvalhais N, Reichstein M, Seixas J et al. (2008) Implications of the carbon cycle steady state assumption for biogeochemical modeling performance and inverse parameter retrieval. Global Biogeochemical Cycles, 22, GB2007, doi: 10.1029/2007GB003033.

Centritto M, Loreto F, Chartzoulakis K (2003) The use of low CO2 to estimate diffusional and non-diffusional limitations of photosynthetic capacity of salt stressed olive saplings. Plant, Cell and Environment, 26, 585-594.

Chaves MM (1991) Effects of water deficits on carbon assimilation. Journal of Experimental Botany, 42, 1-16.

Chaves MM, Pereira JS, Maroco JP et al. (2002) How plants cope with water stress in the field. Photosynthesis and growth. Annals of Botany London, 89, 907-916.

Cornic G (2000) Drought stress inhibits photosynthesis by decreasing stomatal aperture not by affecting ATP synthesis. Trends in Plant Science, 5, 187-188.

Cornic G, Le Gouallec JL, Briantais JM, Hodges M (1989) Effects of dehydration and high light on photosynthesis of two C3 plants. Phaseolus vulgaris L. and Elastostema repens (hour.) Hall f. Planta, 177, 84-90.

Dai YJ, Dickenson RE, Wang YP (2004) A two-big-leaf model for canopy temperature, photosynthesis, and stomatal conductance. Journal of Climatology, 17, 2281-2299. 
De Pury DGG, Farquhar GD (1997) Simple scaling of photosynthesis from leaves to canopies without the errors of big-leaf models. Plant, Cell and Environment, 20, 537-557.

Ellsworth DS (2000) Seasonal $\mathrm{CO}_{2}$ assimilations and stomatal limitations in a Pinus taeda canopy. Tree Physiology, 7, 435-445.

Epron D, Godard D, Cornic G, Genty B (1995) Limitation of net $\mathrm{CO}_{2}$ rate by internal limitation resistance to $\mathrm{CO}_{2}$ transfer in the leaves of two tree species (Fagus sylvatica L. and Castanea sativa Mill.). Plant, Cell and Environment, 18, 43-51.

Ethier GJ, Livingston NJ (2004) On the need to incorporate sensitivity to $\mathrm{CO}_{2}$ transfer conductance into the Farquharvon Caemmerer-Berry leaf photosynthesis model. Plant, Cell and Environment, 27, 137-153.

Evans JR (1999) Leaf anatomy enables more equal access to light and $\mathrm{CO}_{2}$ between chloroplasts. New Phytologist, 143, 93-104.

Evans JR, Loreto F (2000) Acquisition and diffusion of $\mathrm{CO}_{2}$ in higher plant leaves. In: Photosynthesis: Physiology and Metabolism (eds Leegood RC, Sharkey TD, Von Caemmerer S), pp. 321-351. Kluwer Academic Publishers, Dortrecht, the Netherlands.

Farquhar GD, von Caemmerer S, Berry JA (1980) A biochemical model of photosynthetic $\mathrm{CO}_{2}$ assimilation in leaves of $\mathrm{C}_{3}$ species. Planta, 149, 78-90.

Flexas J, Bota J, Escalona JM, Sampol B, Medrano H (2002) Effects of drought on photosynthesis in grapevines under field conditions: an evaluation of stomatal and mesophyll limitations. Functional Plant Biology, 29, 461-471.

Flexas J, Bota J, Loreto F, Cornic G, Sharkey TD (2004) Diffusive and metabolic limitations to photosynthesis under drought and salinity in C3 plants. Plant Biology, 6, 269-279.

Flexas J, Diaz-Espejo A, Galmés J, Kaldenhoff R, Medrano H, Ribas-Carbo M (2007) Rapid variations of mesophyll conductance in response to changes in $\mathrm{CO}_{2}$ concentrations around leaves. Plant, Cell and Environment, 30, 1284-1289.

Flexas J, Escalona JM, Medrano H (1999) Water stress induces different levels of photosynthesis and electron transport rate regulation in grapevines. Plant, Cell and Environment, 22, 39-48.

Flexas J, Ribas-Carbo M, Diaz-Espejo A, Galmes J, Medrano H (2008) Mesophyll conductance to $\mathrm{CO}_{2}$ : current knowledge and future prospects. Plant, Cell and Environment, 31, 602-621.

Flexas J, Ribas-Carbo M, Hanson DT et al. (2006) Tobacco aquaporin NtAQP1 is involved in mesophyll conductance to $\mathrm{CO}_{2}$ in vivo. Plant Journal, 48, 427-439.

Friend AD, Arneth A, Kiang NY et al. (2007) FLUXNET and modelling the global carbon cycle. Global Change Biology, 13, 610-633.

Galmes J, Medrano H, Flexas J (2007) Photosynthetic limitations in response to water stress and recovery in Mediterranean plants with different growth forms. New Phytologist, 175, 81-93.

Giorgi F (2006) Climate change hot-spots. Geophysical Research Letters, 33, doi: 10.1029/2006GL025734.

Giorgi F, Bi X, Pal J (2004) Mean, interannual variability and trends in a regional climate change experiment over Europe. II: climate change scenarios (2071-2100). Climate Dynamics, 23, 839-858.

Goldstein A, Hultman N, Fracheboud JM et al. (2000) Effects of climate variability on the carbon dioxide, water, and sensible heat fluxes above a ponderosa pine plantation in the Sierra Nevada (CA). Agricultural and Forest Meteorology, 101, 113-129. Gracia CA, Tello E, Sabate S, Bellot J (1999) GOTILWA: an integrated model of water dynamics and forest growth. In Ecology of Mediterranean Evergreen Oak Forests (eds Rodà F, Retana J, Gracia CA, Bellot J), pp. 163-179. Springer-Verlag, Berlin.

Grassi G, Magnani F (2005) Stomatal, mesophyll conductance and biochemical limitations to photosynthesis as affected by drought and leaf ontogeny in ash and oak trees. Plant, Cell and Environment, 28, 834-849.

Grunzweig JM, Lin T, Rotenberg E, Schwartz A, Yakir D (2003) Carbon sequestration in an arid land forest. Global Change Biology, 9, 791-799.

Gunasekera D, Berkowitz GA (1992) Heterogeneous stomatal closure in response to leaf water deficits is not a universal phenomenon. Plant Physiology, 98, 660-665.

Haldimann P, Feller U (2004) Inhibition of photosynthesis by high temperature in oak (Quercus pubescens L.) leaves grown under natural conditions closely correlates with a reversible heat dependent reduction of the activation state of ribulose-15-bisphosphate carboxylase/oxygenase. Plant, Cell and Environment, 27, 1169-1183.

Harley P, Loreto F, Di Marco C, Sharkey T (1992) Theoretical considerations when estimating the mesophyll conductance to $\mathrm{CO}_{2}$ flux by analysis of the response of photosynthesis to $\mathrm{CO}_{2}$. Plant Physiology, 98, 1429-1436.

Honeysett JL, Ratkowsky DA (1989) The use of ignition loss to estimate bulk density of forest soils. Journal of Soil Science, $\mathbf{4 0}$, 299-308.

IPCC WGI (2007) Climate Change 2007: climate change impacts, adaptation and vulnerability. (eds Parry ML, Canziani OF, Palutikof JP, van der Linden PJ, Hanson CE), Cambridge University Press, Cambridge, UK.

Jones HG (1973) Moderate-term water stresses and associated changes in some photosynthetic parameters in cotton. New Phytologist, 72, 1095-1105.

Jones HG (1985) Partitioning stomatal and non-stomatal limitations to photosynthesis. Plant, Cell and Environment, 2, 95-104.

Kaiser WM (1987) Effect of water deficit on photosynthetic capacity. Physiologia Plantarum, 71, 142-149.

Kaldenhoff R, Ribas-Carbo M, Flexas J, Lovisolo C, Heckwolf M, Uehlien N (2008) Aquaporins and plant water balance. Plant, Cell and Environment, 31, 658-666.

Keenan T, Garcia R, Friend AD, Zaehle S, Gracia C, Sabate S (2009a) Improved understanding of drought controls on seasonal variation in Mediterranean forest canopy $\mathrm{CO}_{2}$ and water fluxes through combined in situ measurements and ecosystem modelling. Biogeosciences Discussions, 6, 2285-2329.

Keenan T, Niinemets Ü, Sabate S, Gracia C, Peñuelas J (2009b) Process based inventory of isoprenoid emissions: current knowledge, future prospects and uncertainties. Atmospheric Chemistry and Physics Discussions, 9, 6147-6206.

Kowalski AS, Loustau D, Berbigier P et al. (2004) Paired comparisons of carbon exchange between undisturbed and regenerating stands in four managed forests in Europe. Global Change Biology, 10, 1707-1723.

Kramer PJ (1983) Water Relations of Plants. Academic Press, New York, USA. 
Lasslop G, Reichstein M, Kattge J, Papale D (2008) Influences of observation errors in eddy flux data on inverse model parameter estimation. Biogeosciences, 5, 1311-1324.

Lawlor DW, Cornic G (2002) Photosynthetic carbon assimilation and associated metabolism in relation to water deficits in higher plants. Plant, Cell and Environment, 25, 275-294.

Leuning R, Kelliher FM, De Pury DGG, Schulze E-D (1995) Leaf nitrogen, photosynthesis, conductance and transpiration: scaling from leaves to canopies. Plant, Cell and Environment, 18, 1183-1200.

Loreto F, Centritto M (2008) Leaf carbon assimilation in a waterlimited world. Plant Biosystems, 142, 154-161.

Loreto F, Centritto M, Chartzoulakis K (2003) Photosynthetic limitations in olive cultivars with different sensitivity to salt stress. Plant, Cell and Environment, 26, 595-601.

Maroco JP, Rodrigues ML, Lopes C, Chaves MM (2002) Limitations to photosynthesis in grapevine under drought - metabollic and modeling approaches. Functional Plant Biology, 29, 1-9.

McNaughton KG, Black TA (1973) Evapotranspiration from a forest: a micrometeorological study. Water Resource Research, 9, 1579-1590.

Medlyn BE, Loustau D, Delzon S (2002) Temperature response of parameters of a biochemically based model of photosynthesis. I. Seasonal changes in mature maritime pine (Pinus pinaster Ait.). Plant, Cell and Environment, 25, 1155-1165.

Miyazawa SI, Terashima I (2001) Slow development of leaf photosynthesis in an evergreen broad-leaved tree, Castanopsis sieboldii: relationships between leaf anatomical characteristics and photosynthetic rate. Plant, Cell and Environment., 24, 279-291.

Miyazawa SI, Yoshimura S, Shinzaki Y, Maeshima M, Miyake C (2008) Deactivation of aquaporins decreases internal conductance to $\mathrm{CO}_{2}$ diffusion in tobacco leaves grown under longterm drought. Functional Plant Biology, 35, 553-564.

Mott KA, Buckley TN (2000) Patchy stomatal conductance: emergent collective behavior of stomata. Trends in Plant Science, 5, 258-262.

Nemani RR, Keeling CD, Hashimoto H et al. (2003) Climatedriven increases in global terrestrial net primary production from 1982 to 1999. Science, 300, 1560-1563.

Niinemets Ü, Cescatti A, Rodeghiero M, Tosens T (2005) Leaf internal diffusion conductance limits photosynthesis more strongly in older leaves of Mediterranean evergreen broadleaved species. Plant, Cell and Environment, 28, 1552-1566.

Niinemets Ü, Cescatti A, Rodeghiero M, Tosens T (2006) Complex adjustments of photosynthetic potentials and internal diffusion conductance to current and previous light availabilities and leaf age in Mediterranean evergreen species Quercus ilex. Plant, Cell and Environment, 29, 1159-1178.

Niinemets Ü, Diaz-Espejo A, Flexas J, Galmés J, Warren CR (2009a) Role of mesophyll diffusion conductance in constraining potential photosynthetic productivity in the field. Journal of Experimental Botany, 60, 2249-2270.

Niinemets Ü, Diaz-Espejo A, Flexas J, Galmés J, Warren CR (2009b) Importance of mesophyll diffusion conductance in estimation of plant photosynthesis in the field. Journal of Experimental Botany, 60, 2271-2282.

Pons TL, Welschen RAM (2003) Midday depression of net photosynthesis in the tropical rainforest tree Eperua grandiflora: contributions of stomatal and internal conductances, respiration and Rubisco functioning. Tree Physiology, 23, 937-947.

Rambal S, Ourcival J-M, Joffre R, Mouillot F, Nouvellon Y, Reichstein M, Rocheteau A (2003) Drought controls over conductance and assimilation of a Mediterranean evergreen ecosystem: scaling from leaf to canopy. Global Change Biology, 9, 1813-1824.

Reichstein M, Falge E, Baldocchi D et al. (2005) On the separation of net ecosystem exchange into assimilation and ecosystem respiration: review and improved algorithm. Global Change Biology, 11, 1-16.

Reichstein M, Tenhunen JD, Roupsard O et al. (2002) Severe drought effects on ecosystem $\mathrm{CO}_{2}$ and $\mathrm{H}_{2} \mathrm{O}$ fluxes at three Mediterranean evergreen sites: revision of current hypotheses? Global Change Biology, 8, 999-1017.

Reichstein M, Tenhunen J, Roupsard O et al. (2003) Inverse modeling of seasonal drought effects on canopy $\mathrm{CO}_{2} / \mathrm{H}_{2} \mathrm{O}$ exchange in three Mediterranean ecosystems. Journal of Geophysical Research, 108, 4726, doi: 10.1029/2003JD003430.

Renou J, Gerbaud A, Just D, Andre M (1990) Differing substomatal and chloroplastic concentrations in water-stressed wheat. Planta, 182, 415-419.

Root TL, Schneider SH (1995) Ecology and climate: research strategies and implications. Science, 269, 334-341.

Sharkey T (1990) Water stress effects on photosynthesis. Photosynthetica, 24, 651 .

Sharkey T, Badger M (1982) Effects of water stress on photosynthetic electron transport photophosphorylation, and metabolite levels of Xantium strumarium mesophyll cells. Planta, 156, 199-206.

Smirnoff N, Stewart GR (1985) Nitrate assimilation and translocation by higher plants: comparative physiology and ecological consequences. Physiologia Plantarum, 64, 133-140.

Terashima I, Ono K (2002) Effects of $\mathrm{HgCl}_{2}$ on $\mathrm{CO}_{2}$ dependence of leaf photosynthesis: evidence indicating involvement of aquaporins in $\mathrm{CO}_{2}$ diffusion across the plasma membrane. Plant and Cell Physiology, 43, 70-78.

Tezara W, Mitchell SP, Driscoll SP, Lawlor DW (1999) Water stress inhibits plant photosynthesis by decreasing coupling factor and ATP. Nature, 401, 914-917.

Valentini R, DeAngelis P, Matteucci G, Monclus R, Dore S, Scarascia-Mugnozza G (1996) Seasonal net carbon exchange of a beech forest with the atmosphere. Global Change Biology, 2, 199-207.

Vassey TL, Sharkey TD (1989) Mild water stress of Phaseolus vulgaris plants leads to reduced starch synthesis and extractable sucrose-phosphate synthase activity. Plant Physiology, 89, 1066-1070.

von Caemmerer S, Evans JR (1991) Determination of the average partial pressure of $\mathrm{CO}_{2}$ in chloroplasts from leaves of several C3 plants. Australian Journal of Plant Physiology, 18, 287-305.

Wang GL (2005) Agricultural drought in a future climate: results from 15 global climate models participating in the IPCC 4th assessment. Climate Dynamics, 25, 739-753.

Wang Y-P, Baldocchi D, Leuning R, Falges E, Vesala T (2007) Estimating parameters in a land surface model by applying non-linear inversion to eddy covariance flux measurements from eight FLUXNET sites. Global Change Biology, 13, 652-670. 
Wang Y-P, Leuning R (1998) A two-leaf model for canopy conductance, photosynthesis and partitioning of available energy I: model description and comparison with a multilayered model. Agricultural and Forest Meteorology, 91, 89-111.

Warren CR (2004) The photosynthetic limitation posed by internal conductance to $\mathrm{CO}_{2}$ movement is increased by nutrient supply. Journal of Experimental Botany, 55, 2313-2321.

Warren CR (2008a) Soil water deficits decrease the internal conductace to $\mathrm{CO}_{2}$ transfer but atmospheric water deficits do not. Journal of Experimental Botany, 59, 327-334.

Warren CR (2008b) Stand aside stomata, another actor deserves centre stage: the forgotten role of the internal conductance to $\mathrm{CO}_{2}$ transfer. Journal of Experimental Botany, 59, 1475-1487.

Warren CR, Adams MA (2006) Internal conductance does not scale with photosynthetic capacity: implications for carbon isotope discrimination and the economics of water and nitrogen use in photosynthesis. Plant, Cell and Environment, 29, 192-201.
Warren CR, Ethier GJ, Livingston NJ, Grant NJ, Turpin DH, Harrison DL, Black TA (2003) Transfer conductance in second growth Douglas fir (Pseudotsuga menziesii (Mirb.) Franco) canopies. Plant, Cell and Environment, 26, 1215-1227.

Warren CR, Livingston NJ, Turpin DH (2004) Water stress decreases the transfer conductance of Douglas fir (Pseudotsuga menziensii) seedlings. Tree Physiology, 24, 971-979.

Warren CR, Löw M, Matyssek R, Tausz M (2007) Internal conductance to $\mathrm{CO}_{2}$ transfer of adult Fagus sylvatica: variation between sun and shade leaves and due to free-air ozone fumigation. Environmental and Experimental Botany, 59, 130-138.

Wilson KB, Baldocchi DD, Hanson PJ (2000) Spatial and seasonal variability of photosynthetic parameters and their relationship to leaf nitrogen in a deciduous forest. Tree Physiology, 20, 565-578.

$\mathrm{Xu} \mathrm{L}$, Baldocchi D (2003) Seasonal trends in photosynthetic parameters and stomatal conductance of blue oak (Quercus douglasii) under prolonged summer drought and high temperature. Tree Physiology, 23, 865-877. 